\title{
Groundwater quality and underground flow in southern Amazon, Brazil
}

The aim of this study was to evaluate the physical, chemical and microbiological groundwater parameters as well as the mapping of groundwater flow in an urban area of Presidente Médici county in Rondônia State, Southern Amazon. The water samples were collected in 11 wells in April and June of 2017, which corresponds to the dry season in the studied region. Groundwater was acidic, with a large range of nutrients concentration, low turbidity and presence of fecal coliforms in most sampled wells. The parameters that were in disagreement with Consolidation Ordinance No 05/2017/MS and CONAMA no 396/08 Resolution, were pH, turbidity, total coliforms, Escherichia coli, and nitrate. Regarding the microbiological parameter, most of the sampling sites were in disagreement with the established by the legislation that it recommends to be absent in $100 \mathrm{~mL}$, when it is destined for human consumption. Densities found were higher than $112,000 \mathrm{UFC} / 100 \mathrm{~mL}$ for total coliforms and higher than $56,000 \mathrm{UFC} / 100 \mathrm{~mL}$ for Escherichia coli. The $\mathrm{pH}$ ranged from 4.1 to 6.4 , and the turbidity showed a maximum value of $6.7 \mathrm{uT}$. The nitrate concentrations were above the established level (10 mg.L-1) in April in $72.7 \%$, and in June $50 \%$ of the wells, with a maximum of 48.5 mg.L-1. The study of the direction of the underground flow demonstrated the predominance of the flow towards the nearest river, as well as potential contributors of microbiological influences. The results indicate contamination of the groundwater by domestic sewage, being proved by the presence of coliforms and nitrate, being the water unfit for human consumption without adequate treatment.

Keywords: Shallow Wells, Groundwater Quality, Groundwater Flow, Multivariate Statistics.

\section{Qualidade das águas subterrâneas e fluxo subterrâneo no sul da Amazônia, Brasil}

\begin{abstract}
O objetivo deste estudo foi avaliar os parâmetros físicos químicos e microbiológicos das águas subterrâneas, bem como o mapeamento do fluxo das águas subterrâneas em uma área urbana do município de Presidente Médici, no estado de Rondônia, sul da Amazônia. As amostras de água foram coletadas em 11 poços em abril e junho de 2017, o que corresponde à estação seca na região estudada. As águas subterrâneas eram ácidas, com uma ampla faixa de concentração de nutrientes, baixa turbidez e presença de coliformes fecais na maioria dos poços amostrados. Os parâmetros que estavam em desacordo com a Portaria de Consolidação N O 05/2017/MS e com a Resolução CONAMA no 396/08, foram pH, turbidez, coliformes totais, Escherichia coli e nitrato. Em relação ao parâmetro microbiológico, a maioria dos locais de amostragem discordou do estabelecido na legislação que recomenda a ausência em $100 \mathrm{~mL}$, quando destinado ao consumo humano. As densidades encontradas foram superiores a $112.000 \mathrm{UFC} / 100 \mathrm{~mL}$ para coliformes totais e superiores a $56.000 \mathrm{UFC} / 100 \mathrm{~mL}$ para Escherichia coli. O pH variou de 4,1 a 6,4 e a turbidez mostrou um valor máximo de 6,7 uT. As concentrações de nitrato estavam acima do nível estabelecido (10 mg.L-1) em abril em $72,7 \%$ e em junho $50 \%$ dos poços, com um máximo de 48,5 mg.L-1 . O estudo da direção do fluxo subterrâneo demonstrou a predominância do fluxo em direção ao rio mais próximo, bem como potenciais contribuintes de influências microbiológicas. Os resultados indicam contaminação das águas subterrâneas por esgoto doméstico, comprovada pela presença de coliformes e nitratos, sendo a água imprópria para consumo humano sem tratamento adequado.
\end{abstract}

Palavras-chave: Poços Rasos; Qualidade da Água Subterrânea; Fluxo de Água Subterrânea; Estatística Multivariada.

Topic: Engenharia de Recursos Hídricos

Reviewed anonymously in the process of blind peer.
Received: 02/10/2019

Approved: 26/11/2019
Josilena de Jesus Laureano (iD)

Universidade Federal de Rondônia, Brasil http://lattes.cnpq.br/2831334362991086 http://orcid.org/0000-0001-8009-8738 josij.laureano@hotmail.com

\section{Caryne Ferreira Ramos}

Universidade Federal de Rondônia, Brasil http://lattes.cnpq.br/8471241504526836 http://orcid.org/0000-0003-1562-2251 caryne12@gmail.com

Daíse da Silva Lopes (i

Universidade Federal de Rondônia, Brasil http://lattes.cnpq.br/6476811098108643 http://orcid.org/0000-0002-4177-4083 daise_ds12@hotmail.com

\section{Lindolaine Machado de Sousa (iD Universidade Federal de Rondônia, Brasil http://lattes.cnpq.br/6310119731623146 http://orcid.org/0000-0002-9736-5342 lindolaine.sousa@gmail.com \\ Maria Cristina Nery do Nascimento Recktenvald (iD) \\ Universidade Federal de Rondônia, Brasil http://lattes.cnpq.br/2047455613888753 http://orcid.org/0000-0002-1868-8769 mcnn.nery@yahoo.com.br \\ Walkimar Aleixo da Costa Júnior Universidade Federal de Rondônia, Brasil http://lattes.cnpq.br/3208352517690368 http://orcid.org/0000-0001-8989-7966} walkimarcosta@gmail.com

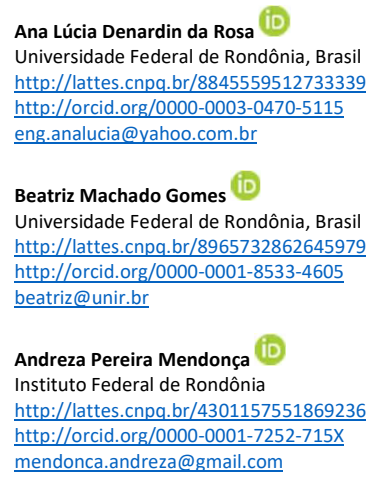

Ana Lúcia Denardin da Rosa (D) Universidade Federal de Rondônia, Brasil http://lattes.cnpq.br/8845559512733339 http://orcid.org/0000-0003-0470-5115 eng.analucia@yahoo.com.br

Beatriz Machado Gomes (iD)

Universidade Federal de Rondônia, Brasil http://lattes.cnpq.br/8965732862645979 http://orcid.org/0000-0001-8533-4605 beatriz@unir.br

Andreza Pereira Mendonça (iD Instituto Federal de Rondônia http://lattes.cnpq.br/4301157551869236 http://orcid.org/0000-0001-7252-715X mendonca.andreza@gmail.com

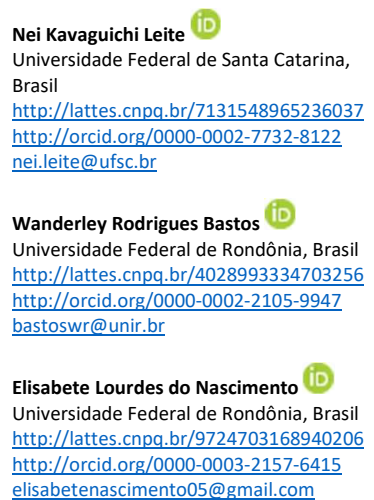

Nei Kavaguichi Leite (10) Vederal de Santa Catarina, http://lattes.cnpq.br/7131548965236037 http://orcid.org/0000-0002-7732-8122 nei.leite@ufsc.br

Wanderley Rodrigues Bastos Universidade Federal de Rondônia, Brasil http://lattes.cnpq.br/40289933334703256 http://orcid.org/0000-0002-2105-9947 bastoswr@unir.br

Universidade Federa de Rondônia, Brasil http://lattes.cnpq.br/9724703168940206 elisabetenascimento05@gmail.com

\section{Referencing this:}

LAUREANO, J. J.; RAMOS, C. F.; LOPES, D. S.; SOUSA, L. M.; RECKTENVALD, M. C. N.; COSTA JÚNIOR, W. A.; ROSA, A. L. D.; GOMES, B. M.; MENDONÇA, A. P.; LEITE, N. K.; BASTOS, W. R.; NASCIMENTO, E. L.. Groundwater quality and underground flow in southern Amazon, Brazil. Revista Ibero Americana de Ciências Ambientais, v.10, n.6, p.206-217, 2019. DOI: http://doi.org/10.6008/CBPC21796858.2019.006.0018

DOI: 10.6008/CBPC2179-6858.2019.006.0018 


\section{INTRODUCTION}

Adequate water supply in quantity and quality is essential to ensure socioeconomic development reflecting on human health conditions, improvements in life quality and economic productivity (GREY et al., 2007). However, studies conducted in different parts of the world reveal that the use of water for the consumption of human populations is troublesome, mainly due to the contamination of this water resources linked to urban growth, industrial and agricultural development, which release waste and effluents in the environment (FAMIGLIETTI, 2014; VORÖSMARTY et al., 2010; SILVA et al., 2009; VORÖSMARTY et al., 2000).

Groundwater have assumed a strategic role as a water source because currently there is a progressive increase in the use of this source due to the fact that it is more protected than surface waters, exhibit a large extension of their reserves and also allows the flexibility for installation of low-cost power driven pump wells in various places within the watershed (ALBUQUERQUE FILHO et al., 2011; HISCOCK, 2011). Groundwater use in Brazil is empirical, improvised and uncontrolled (SILVA et al., 2014). The loss of quality of these water resource has been noted due to the land use and occupation and problems with groundwater contamination have been already been identified in Rondônia State.

Several studies have been carried out with this subject as those carried out in the municipalities of Ariquemes by Faustino et al. (2013), in the municipality of Ji-Paraná by Ferreira et al. (2014), Nunes et al. (2012) and Silva et al. (2009), and in the municipality of Vilhena by Oliveira et al. (2015). All these studies observed groundwater contamination due to the contact of these waters with domestic sewage and fertilizer use in the surroundings of the studied wells. In this work we present a groundwater quality study from urban wells of Presidente Médici county, Southern Amazon, aiming to investigate the status of anthropogenic groundwater pollution, particularly that caused by fecal coliforms and nitrate.

\section{MATERIALS AND METHOD}

\section{Study Area}

The present study was conducted in the municipality of Presidente Médici, located in the state of Rondônia, Southwestern Amazon in Brazil. It is located at latitude 1110'33" S and longitude 61954'03" W. The municipality has an estimated population of 22,319 inhabitants (IBGE, 2017). The altitude is about 211 $\mathrm{m}$ above sea level and climate in the region is classified as Tropical monsoon climate (Am) (Peel et al. 2007), which is characterized by a mean temperature of $26 \circ \mathrm{C}$ and a mean annual precipitation of approximately 2,250 mm (SANTOS et al. 2019).

Eleven sampling sites (residential shallow wells) were randomly selected within the urban study area, comprising distinct regions within the city of Presidente Médici (Figure 1). Sampling was performed in April and June of 2017. The geographical coordinates were recorded using a GPS unit (Garmin Etrex Vista H 2.8"). The distance between well and pit, water level in the well and pit depth were measured using a measuring tape. We also checked the presence of cover and/or coating in the wells. 


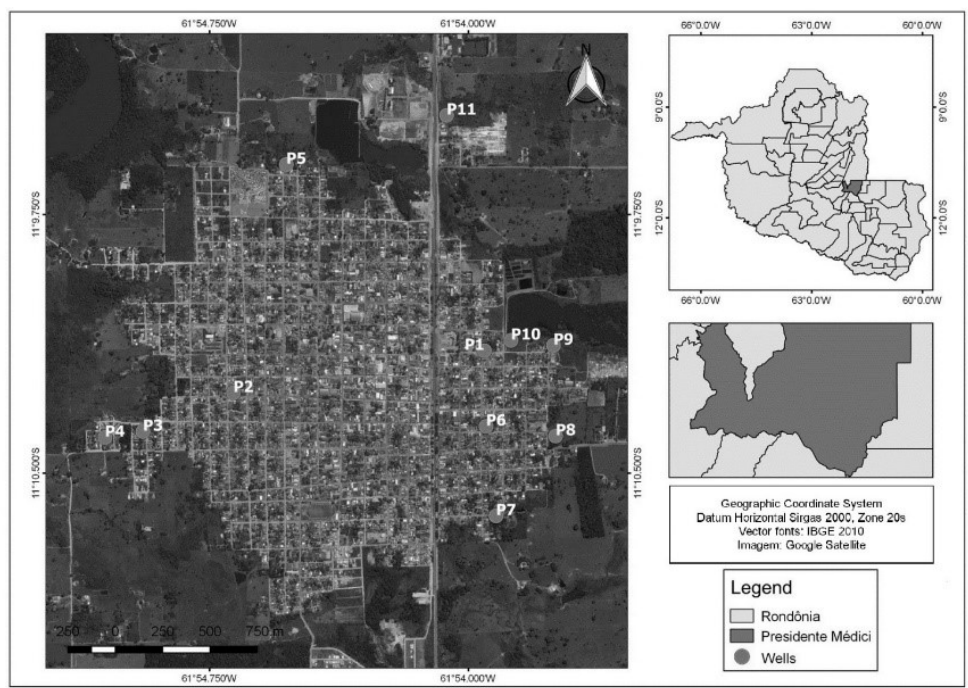

Figure 1: Location of Presidente Médici district, Rondônia, Brazil.

\section{Sample collection and analytical procedures}

Groundwater was sampled using a disposable sampling bailers. While in the field, water samples were either kept in plastic graduated cylinders to proceed with physical-chemical analysis. An aliquot was taken to measure electrical conductivity (using an Amber Science meter, model 2052), pH and temperature (using an Orion meter, model 250A), turbidity using a bench turbidimeter (HACH, model 2100 P). Dissolved oxygen was determined by Winkler titration method (APHA et al., 1995), and total dissolved solids was performed following APHA (1995).

Additional aliquots were then filtered through cellulose acetate membranes $(0.45 \mu \mathrm{m}$ nominal pore size), and stored in high density polyethylene (HDPE) for the analysis of dissolved inorganic nutrients. For the total phosphorus analysis, raw water sample was used. Nitrate, nitrite, ammonia, dissolved phosphorus and total phosphorus analyzes were performed by colorimetric method, determined by spectrophotometer technique, following the Standard Methods for the Examination of Water and Wastewater (APHA et al., 1995).

Samples for microbiological analysis was collected in sealed mineral water bottles $(500 \mathrm{~mL})$, opened at the time of collection, where the mineral water was discarded and the bottle 'rinsed' with the water from the actual sampled well, and kept refrigerated until the time of analysis. Total coliforms and Escherichia coli analyzes were performed according to the chromogenic membrane filter method described in APHA (1995). All analyzes were performed at the Laboratory of Limnology and Microbiology - LABLIM at the Federal University of Rondônia - UNIR, Ji-Paraná campus.

\section{Underground flow}

The analysis of the underground flow was based on the geographical coordinates obtained from a GPS unit (Garmin Etrex Vista H 2.8") and by the piezometric surface (relationship between well altimetry and the static water level) which were used to generate trend maps of groundwater flow direction with the software Surfer 8 . The altimetric levels of possible contamination sites such as cemeteries and gas stations 
were also obtained. For data interpolation the kriging method was used, which is considered a good methodology for mathematical interpolation of values and is indicated for low and close values (Lobler et al. 2013).

\section{Statistical analysis}

Exploratory data analysis was performed using descriptive statistics. Data were further analyzed using multivariate statistics, which have been widely employed to evaluate groundwater quality (WU et al., 2014; RAVIKUMAR et al., 2017; LEITE et al., 2018). PCA was carried out to identify main factors controlling groundwater hydrochemistry, and the parameters included in PCA were total coliforms, Escherichia coli, temperature, $\mathrm{pH}$, electrical conductivity, turbidity, total dissolved solids, dissolved oxygen, total phosphorus, ammonium, nitrite, nitrate, pit depth, well depth, depth, P.S: surface depth, distance well-pit. Data normality was evaluated using Shapiro-Wilk's generalized (W) test before the PCA analysis, and non-normally distributed data were logarithmically transformed.

\section{RESULTS}

\section{Microbiology and hydrochemistry of groundwater}

Total coliforms, E. coli, turbidity, $\mathrm{pH}$ and nitrate were the water quality parameters in disagreement with the Brazilian water quality standards (Ministry of Health Ordinance $\mathrm{N}^{\circ} 05$ of 2017 and CONAMA Resolution $\mathrm{N}^{\text {0. }} 396$ of 2008). The results of microbiological analysis are shown in Table 1. A total of $100 \%$ of the households analyzed in both samplings exhibited the presence of total coliforms.

Table 1. Total coliforms and Escherichia coli in groundwater in Presidente Médici, Brazil.

\begin{tabular}{|c|c|c|c|c|}
\hline \multirow[t]{2}{*}{ Wells } & \multicolumn{2}{|l|}{$\begin{array}{l}\text { Total coliforms } \\
\text { (CFU/100mL) }\end{array}$} & \multicolumn{2}{|l|}{$\begin{array}{l}\text { Escherichia coli } \\
\text { (CFU/100mL) }\end{array}$} \\
\hline & Rainy-dry (April) & Dry (June) & Rainy-dry (April) & Dry (June) \\
\hline 1 & 2.100 & 8.032 & 100 & 32 \\
\hline 2 & 9.002 & 37.000 & 2 & 14.000 \\
\hline 3 & 2.005 & 32 & 5 & Absent \\
\hline 4 & 120 & 6.005 & 10 & 5 \\
\hline 5 & 2.040 & 14.000 & 40 & 2.000 \\
\hline 6 & 1.025 & 1.004 & 25 & 4 \\
\hline 7 & 4.060 & 19.000 & 60 & 1.000 \\
\hline 8 & 15.000 & 57.000 & 5.000 & 1.000 \\
\hline 9 & 6.110 & $\begin{array}{l}>112.000 \\
\text { (dilution 1.000x) }\end{array}$ & 110 & $\begin{array}{l}>56.000 \\
\text { (dilution 1.000x) }\end{array}$ \\
\hline 10 & 2.120 & N/A & 2.000 & N/A \\
\hline 11 & 4.000 & 59 & 1.000 & 10 \\
\hline $\begin{array}{l}\text { Consolidation } \\
\text { Ordinance no 05/2017 } \\
\text { MH CONAMA 396/08 }\end{array}$ & \multicolumn{2}{|l|}{ Absent/100mL } & \multicolumn{2}{|l|}{ Absent/100mL } \\
\hline
\end{tabular}

$\mathrm{N} / \mathrm{A}=$ Not available

The highest density of total coliforms was found in April (month representing the rainy-dry transition period) at site 8 , with $15,000 \mathrm{CFU} / 100 \mathrm{~mL}$, and in June (month representing the dry season), at site 9 where it was detected a density higher than $112,000 \mathrm{CFU} / 100 \mathrm{~mL}$ after a 1,000-fold dilution. Total coliforms are 
associated with the environment and can be found in soils and waters not necessarily contaminated, as they are free-living organisms (SPERLING, 2014).

Regarding E. coli, the results from April showed all wells to be in disagreement with the Brazilian water quality standards, which recommends the absence of $E$. coli in water intended for human consumption. For June, only site 3 have not shown this bacterial group. The highest densities found were 5,000 CFU/100mL (site 8 ) in April, and higher than $56,000 \mathrm{CFU} / 100 \mathrm{~mL}$ for site 9 in June. E. coli indicates that water is contaminated by human feces of warm-blooded animals with the potential to transmit waterborne diseases (SPERLING, 2014).

For drinking purposes, the Ministry of Health Ordinance $N^{0 .}$ 05/2017 states that to achieve the microbiological water quality the turbidity standard must be met, and recommends as a maximum contaminant level-MCP for disinfected groundwater, the limit of 5uT for any sample. CONAMA Resolution 396/08 does not establish turbidity value. Only during the rainy to dry season (April) there were sites in disagreement with the referred legislation (sites 8 and 10) with turbidity of 6.68uT and 6uT, respectively, both with partial coating, which facilitates infiltration and subsequent elevation of turbidity.

The $\mathrm{pH}$ values are presented in Figure 2 where it is possible to check that $27 \%$ of the wells $(1,2$ and 9) during April were within the legislation, while in June $100 \%$ of the sites were outside the established by the legislation, which recommends the $\mathrm{pH}$ to range from 6.0 to 9.5. CONAMA Resolution 396/08 does not establish a range of values for $\mathrm{pH}$.

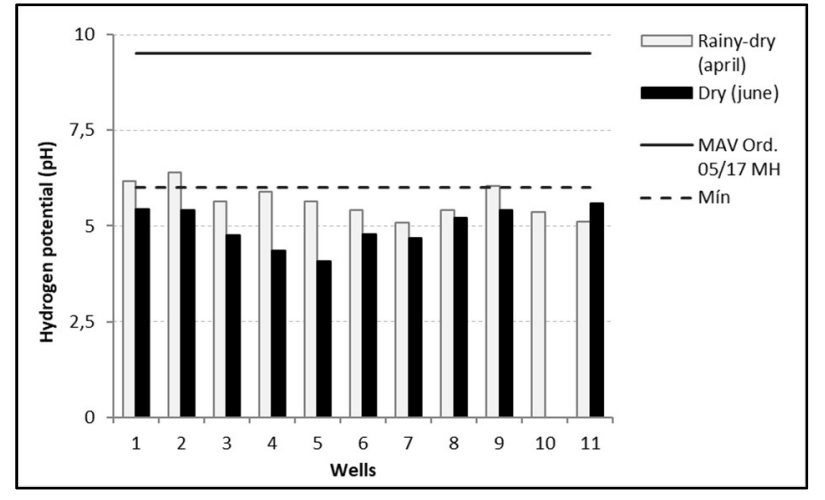

Figure 2: $\mathrm{pH}$ values for groundwater in Presidente Médici during April and June 2017.

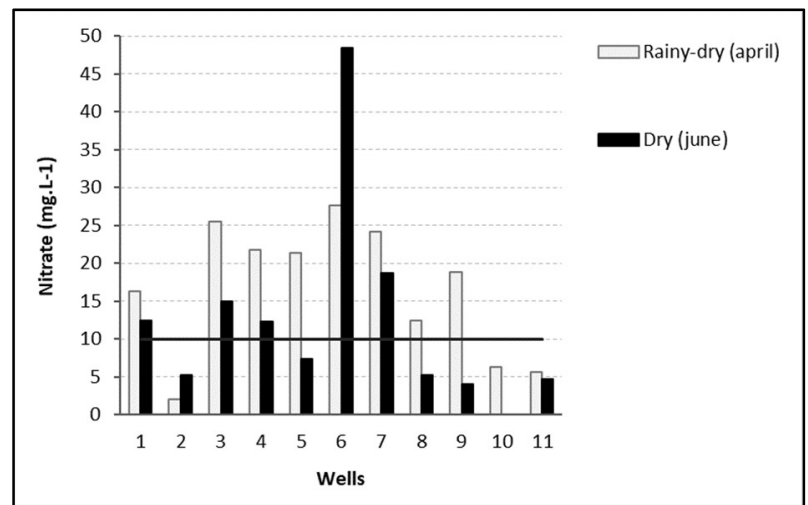

Figure 3: Nitrate-N (mg. $\left.\mathrm{L}^{-1}\right)$ concentrations in Presidente Médici's groundwater in April and June 2017.

Brazilian laws (Ministry of Health Ordinance $N^{\circ} .05 / 2017$ and CONAMA 396/08) set the maximum nitrate value (as $\mathrm{N}$ ) of $10 \mathrm{mg} \cdot \mathrm{L}^{-1}$. Figure 3 presents the results of nitrate- $\mathrm{N}$ in groundwater ranging from 2 to $27.5 \mathrm{mg} \cdot \mathrm{L}^{-1}$ in the rainy-dry season (April), with a mean value of $16.5 \mathrm{mg} . \mathrm{L}^{-1}$, where $72.7 \%$ of the samples

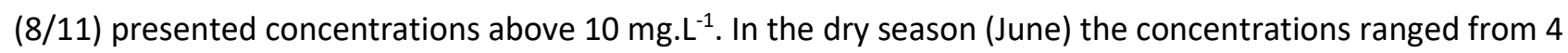
to $48.4 \mathrm{mg} . \mathrm{L}^{-1}$, with an average of $13.3 \mathrm{mg} \cdot \mathrm{L}^{-1}$, where $50 \%$ of the wells have not fitted with the legislation.

\section{Principal Components Analysis (PCA)}

The matrix for the analysis of the principal components (PCA) was constituted by values of the 
physicochemical and microbiological parameters referring to the two studied periods, as well as with information about the characteristics of the wells, in order to observe possible seasonal patterns of the studied variables.

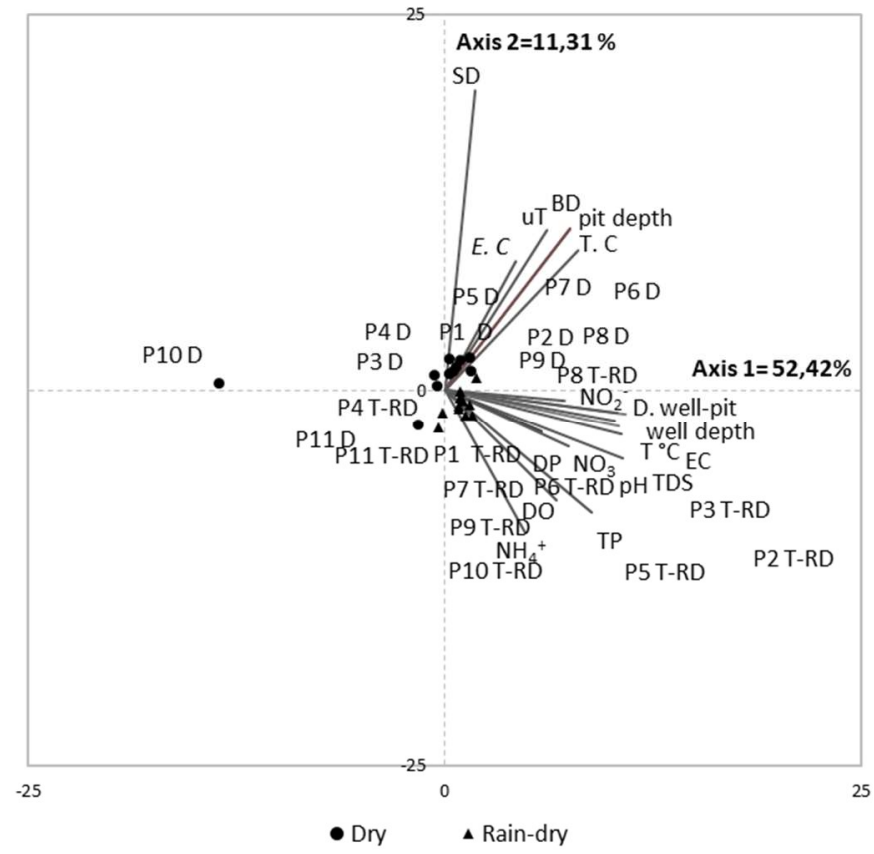

Figure 4. Biplot of hydrochemical variables and constructive characteristics of urban wells in the municipality of Presidente Médici for the rain-dry (April) and dry (June) periods of 2017. The abbreviations correspond to the following variables: TC: total coliforms, E. C: Escherichia coli, $\mathrm{T}^{\circ} \mathrm{C}$ : temperature, $\mathrm{pH}$ : hydrogen potential, EC: electrical conductivity, UT: turbidity, TDS: total dissolved solids, DO: dissolved oxygen, TP: total phosphorus, DP: dissolved phosphorus, $\mathrm{NH}_{4}$ : ammonium, $\mathrm{NO}_{2}$ : nitrite, $\mathrm{NO}_{3}$ : nitrate, Pit Depth, BD: Bottom Depth, SD: Surface Depth, Pit-well Distance, well depth, pit depth.

The projection of the data in the first two axes of the PCA is presented in Figure 4. It is observed the split of the points in two distinct groups according to seasonality, one group corresponding to the rainy-dry season (April) and the other to the dry period (June). Although the two groups are close in the projection, they were on opposite sides of axis 1 . Axis 1 explained $52.4 \%$ of the data variability while axis 2 explained $11.3 \%$, so the total variance explained in both axes was $63.7 \%$. The contribution of the variables to the two new components (axis) are presented in Table 2.

The variables that showed the highest contribution to axis 1 were well depth $(0.967), \mathrm{pH}(0.952)$, temperature (0.945), and electrical conductivity (0.931). Axis 2 was formed by surface depth (0.827), bottom depth (0.448), pit height $(0.448)$, and turbidity $(0.442)$. The results show the high correlation between constructive aspects such as surface and bottom depth and pit depth with the groundwater turbidity.

Table 2. Correlation of the variables under study in axes 1 and 2 resulting from the Principal Component Analysis (PCA).

\begin{tabular}{|l|l|l|l|}
\hline Variables & Abbreviations & Axis 1 & Axis 2 \\
\hline Total coliforms & T.C & 0,714 & 0,387 \\
\hline Escherichia coli & E. C & 0,380 & 0,357 \\
\hline Temperature & $\mathrm{T}^{\circ} \mathrm{C}$ & 0,945 & $-0,121$ \\
\hline $\mathrm{pH}$ & $\mathrm{pH}$ & 0,952 & $-0,190$ \\
\hline Electrical conductivity & EC & 0,931 & $-0,098$ \\
\hline Turbidity & UT & 0,549 & 0,442 \\
\hline Total dissolved solids & TDS & 0,910 & $-0,086$ \\
\hline Dissolved oxygen & DO & 0,600 & $-0,306$ \\
\hline Total phosphorus & TP & 0,787 & $-0,339$ \\
\hline
\end{tabular}




\begin{tabular}{|l|l|l|l|}
\hline Dissolved phosphorus & $\mathrm{DP}$ & 0,516 & $-0,116$ \\
\hline Ammonium & $\mathrm{NH}_{4}$ & 0,433 & $-0,395$ \\
\hline Nitrite & $\mathrm{NO}_{2}$ & 0,639 & $-0,029$ \\
\hline Nitrate & $\mathrm{NO}_{3}$ & 0,661 & $-0,157$ \\
\hline Well depth & & 0,967 & $-0,064$ \\
\hline Pit depth & & 0,667 & 0,448 \\
\hline Bottom depth & $\mathrm{BD}$ & 0,667 & 0,448 \\
\hline Surface depth & $\mathrm{SD}$ & 0,161 & 0,827 \\
\hline Distance between well and pit & D. well-pit & 0,925 & $-0,060$ \\
\hline Explained variance & $52,42 \%$ & $11,31 \%$ \\
\hline Total variance explained & $63,73 \%$ & \\
\hline
\end{tabular}

\section{Underground flow}

In the study area a similar behavior was observed for the direction of flow in the two evaluated seasons (dry-to-wet and dry), with no variations due to seasonality. It was observed the predominance of the flow towards the southeast and from the whole central part of the cartogram towards the northeast, northwest, and west direction of the cartogram (Figure 5). Points 5, 6, and 8 correspond to the potentiometric highs that act as a drainage divider whereas points 4 and 9 are the potentiometric depressions.

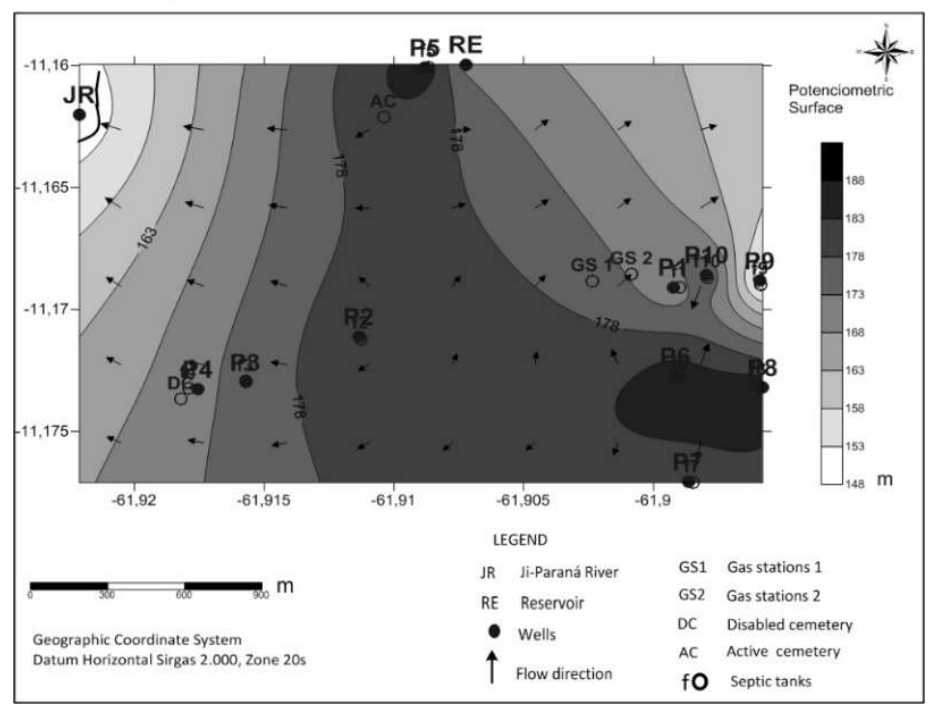

Figure 5. Underground flow of the city of Presidente Médici, Rondônia.

Sites with high coliform density are located in the areas with the lowest altimetry. This result confirms the influence of septic tanks that are located near the wells. The map shows an important river (Ji-Paraná River) of the studied region in its northwestern portion (Figure 4), and this watercourse probably receives the influence of wells and septic tanks present in this region. In Figure 4 it is also possible to identify the location of possible points of contamination by other substances not studied in the present work, such as the BTEX, due to the presence of gas stations and necro-leachate, coming from the disabled cemetery and the active cemetery of the city. Water from both wells and streams in the region may be receiving a contaminant load from the contamination plume from these locations.

\section{DISCUSSION}

Ordinance $\mathrm{N}^{0} \cdot 05 / 2017$ and CONAMA Resolution $\mathrm{N}^{0} \cdot 396 / 08$ establishes that water intended for 
human consumption must be absent from both total and E. coli coliforms, thus groundwater from the analyzed wells is inappropriate for human consumption without proper treatment. The high values found in the wells indicate contamination by sanitary sewage and can be explained by the constructive characteristics of the wells and pits. Factors such as the upper pit level when compared to the well is a facilitator of the effluent flow towards the well, as well as the lack of coating on the walls of the well, both contributes to the contamination of groundwater resources.

Some wells, such as in site 2, had surface water input because the well water level was below the septic tank liquid level. This can be confirmed by marks on the inner wall of the well. This external water supply associated with the breeding of domestic animals in the surrounding area and their potential access to the well are the main factors responsible for the water contamination. Ferreira et al. (2014) observed a strong positive correlation between the constructive aspects and the microbiological results in the area they studied. Of the 7 properties evaluated, only 3 showed no E. coli contamination in groundwater, which had in common the use of concrete drainage pipe as a coating.

Leite et al. (2018) reinforce the need to improve water hygiene and treatment conditions prior to human use, as well as installation care, the development of groundwater quality monitoring programs and also the elaboration of specific water quality indices to address the heterogeneity of environments and water uses by which this resource is employed.

However, it is also important to highlight that even in wells with good constructive characteristics the presence of coliform bacteria was observed. An example of this was site 7 , which even though it had a distance of $24.3 \mathrm{~m}$ from the pit, exceeding the $15.0 \mathrm{~m}$ recommended by the regulatory standard (NBR 7.229/93), a cemented area around the well, and using a septic tank for the destination of domestic sewage, showed contamination by total coliforms and E. coli in both periods analyzed, suggesting a possible transit of bacteria in the water table.

The high values of coliforms found in the present study do not differ from the results of studies conducted in other cities of the state of Rondônia. Oliveira et al. (2015) found 73\% (8/11) of the studied shallow wells in Vilhena during the rainy season and 9\% (1/11) during the dry period in disagreement with the legislation for E. coli, whereas $100 \%$ of wells $(11 / 11)$ showed contamination at the rainy season by total coliforms and $36 \%(4 / 11)$ in the dry period. Faustino et al. (2013) found total coliforms and E. coli in $100 \%$ of the analyzed sampling sites in the municipality of Ariquemes.

Regarding turbidity Oliveira et al. (2015) found only 1 of the 12 wells in Vilhena with turbidity (7uT) above the recommended by the legislation. According to the authors, the wells with lower depth showed high turbidity values, which does not represent a health risk, but makes the treatment for disinfection difficult, since the particles serve as a shield for microorganisms.

Oliveira et al. (2015) recorded pH values between 4.14 and 4.94 in the dry season (August) and between 4.72 and 6.30 in the rainy season (December) in the municipality of Vilhena. Faustino et al. (2013) observed values below the established by legislation in all wells they analyzed in Ariquemes. Silva et al. (2009) 
observed an average $\mathrm{pH}$ of 4.30 in the municipality of Ji-Paraná. Leite et al. (2011) found average pH values of 5.4 in rural shallow wells in Ji-Paraná, with the median in the wet (rainy) season (5.3) slightly lower than in the dry season (5.7).

With this we can say that the values registered in the present research were similar to those observed in other studies conducted in the state of Rondônia, and this allowed us to classify the groundwater in the studied region in the acid to slightly acid categories. The study by Farias et al., (2003) have shown that regions with tropical climate where biological degradation is more pronounced, the evolution of organic matter in the anaerobic phase favors the production of organic acids, resulting in the production of more acidic $\mathrm{pH}$ solutions.

In the study developed by Silva et al. (2009), observed that $78 \%$ of the wells studied in the city of JiParaná showed values above the limits established for nitrate, with the highest concentration of $239 \mathrm{mg} \cdot \mathrm{L}^{-1}$. The authors associated this result with the short distance between wells and septic tanks, lack of sanitary protection cover and the presence of chicken or kennel around the wells. Nunes et al. (2012) found maximum nitrate values of $26.2 \mathrm{mg} \cdot \mathrm{L}^{-1}$ in shallow wells in Ji-Paraná, considering the cultivation of vegetables as the source of contamination, since the wells located near the cultivation has presented the higher concentrations of this nutrient.

In a study conducted in the rural region of Ji-Paraná county, Leite et al. (2011) found varying nitrate concentrations in rural shallow wells, with only one site exhibiting concentrations higher than $10 \mathrm{mg}^{\mathrm{L}} \mathrm{L}^{-1}$. These authors also observed that most of the studied wells showed higher concentrations of this nutrient during the rainy season, attributing this fact to an important superficial contribution (both overland flow and septic tanks leakage).

Nitrate is the most prevalent groundwater pollutant due to sources such as fertilizer use, livestock and in situ sanitation systems (VARNIER et al., 2002). Nitrate can induce methemoglobinemia (prevent the transport of oxygen into the bloodstream of infants) and the potential formation of carcinogenic nitrosamines and nitrosamides (ALABURDA et al., 1998). These arise as a product of nitrite ingested or formed by the bacterial reduction of nitrate, with amines and amides present in foods, occurring at a $\mathrm{pH}$ between 2.5 and 3.5 which is similar to that produced in stomach (BIGUELINI et al., 2012).

Nitrosanines have been recognized in animal experiments as a potential carcinogen for stomach, esophageal and liver cancer, but no direct link with human cancer can be concluded (CORTECCI, 2017) as researches are still inconclusive. However, recent studies have shown that women who drank water with high nitrate levels (>2.46 mg. $\mathrm{L}^{-1}$ ) were three times more likely to have breast cancer than those less exposed $\left(<0.36 \mathrm{mg}^{-1} \mathrm{~L}^{-1}\right)$ (SILVA et al., 2014).

According to Varnier et al. (2010), the urban expansion without adequate sanitary sewage system generates a nitrate contaminant load, with potential to reach aquifers and consequently compromise the groundwater quality. In their study, the sharp drop in nitrate concentrations in deeper waters reinforces the hypothesis of anthropic origin, since the source of contamination may be associated with sewage infiltration, 
once shallow wells had shown the highest concentrations.

Determining the predominant form of nitrogen may indicate the pollution stage, where recent pollution is associated with nitrogen in the form of ammonia, while older pollution may be associated with nitrate (SPERLING, 2014). According to Vanier et al. (2002), there is a predominance of less oxidized compounds near the source of contamination, stable under reducing conditions, as it moves away from the source there is a gradual increase in nitrate concentration, since it undergoes the process of nitrification.

It is important to highlight the presence of nitrogen compounds in the form of ammonium and nitrite in the groundwater samples analyzed in Presidente Médici, but these occurred in low concentrations (below the limits allowed by current legislation), which favored nitrate as the predominant fraction among the dissolved inorganic nitrogen forms.

Although a maximum of $10 \mathrm{mg} \cdot \mathrm{L}^{-1}$ of nitrate (as nitrogen) is allowed in drinking water, values between 3 and $10 \mathrm{mg} \cdot \mathrm{L}^{-1}$ may serve as a warning for the onset of water body contamination (BIGUELINI et al., 2012). Potential sources of pollution to groundwater include untreated sewage, gas stations, cemeteries, and car washes that generate foam and waste from hydrocarbons, petroleum, oils, greases, and necro-leachate (LOBLER et al., 2013).

Free aquifers present a higher risk of contamination because they are permeable to the flow of various contaminants. Thus, contamination is directly linked to the type of activity performed in the region, the contaminant itself and its pollutant load (OLIVEIRA et al., 2016). The direction of the underground flow indicates a possible interaction with the watercourse (LOBLER et al., 2013; LOBLER et al., 2015). The possible contribution of underground flow to the Commemoration River flow was observed in a study conducted in the municipality of Vilhena, also located in the state of Rondônia (OLIVEIRA et al., 2015; BARROS et al., 2016).

Studying the direction of flow along with the potential contamination points helps to identify areas of higher contamination risk, as there are gas stations and graveyards located in areas with flow directed to potentiometric depressions. These areas receive direct influence in the case of the formation of contaminant plume from these enterprises. Determining the direction of groundwater flow becomes an important tool for identifying the potential contamination of groundwater resources (FERREIRA et al., 2014), as it allows planning and predicting actions aimed to minimize the risks associated with contamination points.

\section{CONCLUSIONS}

The present study showed that the water is unfit for human consumption because the $\mathrm{pH}$, turbidity, total coliforms, Escherichia coli and nitrate have presented values and concentrations in disagreement with drinking water legislation. Here we highlight the presence of nitrate in high concentrations, which can potentially lead to diseases. Groundwater contamination occurs due to the presence of pit latrines near the wells. The constructive characteristics of wells and pits are the main factor responsible for the contamination of groundwater resources in the studied region.

Principal Component Analysis identified changes in groundwater characteristics between the two 
seasonal periods evaluated: rainy-dry and dry seasons. The study of the direction of the underground flow showed that the wells and the river may be receiving contaminants from contamination points located in the high potentiometers. Implementation of the sewerage system, expansion and maintenance of the water supply network and continuous monitoring of water quality by environmental and health agencies is recommended.

ACKNOWLEDGMENTS: We would like to acknowledge CNPq and PIBIC for funding. Biogeochemistry Laboratory / UNIR of Ji-Paraná campus; Wolfgang Christian Pffeifer / UNIR Environmental Biogeochemistry Laboratory of Porto Velho campus; Sanitation Laboratory / UNIR of Ji-Paraná campus; Seed Laboratory / IFRO of Ji-Paraná campus; Limnology and Microbiology Laboratory / UNIR of Ji-Paraná campus.

\section{REFERENCES}

ALABURDA, J.; NISHIHARA, L.. Presença de compostos de nitrogênio em águas de poços. Revista de Saúde Pública, v.32, p.160-165, 1998. DOI:

http://dx.doi.org/10.1590/S0034-89101998000200009

ALBUQUERQUE FILHO, J. L.; BARBOSA, M. C.; AZEVEDO, S. G.; CARVALHO, A. M.. O papel das águas subterrâneas como reserva estratégica de água e diretrizes para a sua gestão sustentável. Revista de Recursos Hídricos, v.32, n.2, p.53-61, 2011. DOI: https://doi.org/10.5894/rh32n2-5

APHA; AWWA; WEF. American Pharmacists Association. American Water Works Association. World Economic Forum. Standard methods for the examination of water and wastewater. 19 ed. Washington, 1995

ABNT. Associação Brasileira de Normas Técnicas. NBR 7229. Projeto, construção e operação de sistemas de tanques sépticos. Rio de Janeiro: ABNT, 1993.

BARROS, C. G. D.; ROSA, A. L. D.; SILVA, J. L. S.; OLIVEIRA, G. A.; TEIXEIRA, L. G.; SAMPAIO, R. B. S.. Superfície potenciométrica e possíveis fontes de contaminação do aquífero Parecis no município de Vilhena-RO, BR. Revista Monografias Ambientais v.15, n.8, p.74-84, 2016. DOI: http://dx.doi.org/:10.5902/2236130800000

BIGUELINI, C. P.; GUMY, M. P.. Saúde ambiental: Índices de nitrato em águas subterrâneas de poços profundos na região sudoeste do Paraná. Revista UNIOESTE, v.14, p.153-175, 2012.

BRASIL. Ministério da Saúde (MS). Portaria de consolidação n.5, de 3 de outubro de 2017. Dispõe sobre os procedimentos de controle e de vigilância da qualidade da água para consumo humano e seu padrão de potabilidade. Brasília: DOU, 2017.

BRASIL. Conselho Nacional do Meio Ambiente (CONAMA). Resolução n.396 de 03 de abril de 2008. Dispõe sobre a classificação e diretrizes ambientais para o enquadramento das águas subterrâneas. Brasília: DOU, 2008.

CORTECCI, G.. Geologia e Saúde. Companhia de Pesquisa de Recursos Minerais- CPRM. Gestão territorial Geologia e
Geosaúde. 2017.

FAMIGLIETTI, J. S.. The global groundwater crisis. Nature Climate Change, v.4, p.945-948, 2014. DOI: https://doi.org/10.1038/nclimate2425

FARIAS, W. M.; MARTINS, E. S.; CARDOSO, F. B. F.; CARVALHO, J. C.. A influência do oxi-hidróxido de Fe matricial no comportamento mecânico de solos tropicais em áreas de disposição de resíduos sólidos. Revista Espaço e Geografia, v.6, p.115-131, 2003.

FAUSTINO, E.; VANZELLA, M.; MENEGUETTI, D. U. O.; ZAN, R. A.. Avaliação da qualidade de água de poços rasos ou comuns da cidade de Ariquemes, Rondônia, Brasil. Revista Cientifica da Faculdade de Educação e Meio Ambiente, v.4, n.2, p.65-78, 2013

DOI: https://doi.org/10.31072/rcf.v4i2.190

FERREIRA, R. F.; MENDONÇA, A. P.; CUZZOUL, E. R.; NASCIMENTO, E. L.; STACHIW, R.; FERREIRA, E.. Análise microbiológica e direção do fluxo subterrâneo do lixão desativado em Ji-Paraná, Rondônia. Revista Brasileira de Ciências da Amazônia, v.3, p.37-46, 2014.

GREY, D., \& SADOFF, C. W. (2007). Sink or swim? Water security for growth and development. Water policy, 9(6), p.545-571. DOI: https://doi.org/ 10.2166/wp.2007.021.

HISCOCK, K. M.. Groundwater in the 21st century-meeting the challenges. In: SUSTAINING GROUNDWATER RESOURCES. Anais. Springer, 2011. p.207-225. DOI: https://doi.org/10.1007/978-90-481-3426-7 13

IBGE. Instituto Brasileiro de Geografia e Estatística. Sistema Agregador de Informações sobre Municípios e Estados do IBGE. Rio de Janeiro: IBGE, 2017.

LEITE, N. K.; KRUSCHE, A. V.; CABIANCHI, G. M.; BALLESTER, M. V. R.; VICTORIA, R. L.; MARCHETTO, M.; SANTOS, J. G. D. Groundwater quality comparison between rural farms and riparian wells in the western Amazon, Brazil. Química Nova, v.34, n.1, p.11-15, 2011. DOI: http://dx.doi.org/10.1590/S0100-40422011000100003 
LEITE, N. K.; STOLBERG, J.; CRUZ, S. P.; TAVELA, A. O.; SAFANELLI, J. L.; MARCHINI, H. R.; EXTERKOETTER, R.; LEITE, G. M. C.; KRUSCHE, A. V.; JOHNSON, M. S.. Hydrochemistry of shallow groundwater and springs used for potable supply in Southern Brazil. Environmental Earth Sciences, v.77, n.3, p.80, 2018. DOI: http://dx.doi.org/10.1007/s12665-018$\underline{7254-4}$

LOBLER, C. A; SILVA, J. L. S.. Vulnerabilidade à contaminação das águas subterrâneas do município de Nova Palma, Rio Grande do Sul, Brasil. Revista Ambiente e água, v.10, 2015. DOI: http://dx.doi.org/10.4136/ambi-agua.1390

LOBLER, C. A.; SILVA, J. L. S.; MARTELLI, G. V.; ERTEL, T. Pontos Potenciais de Contaminação e vulnerabilidade Natural das águas Subterrâneas do Município de Restinga Seca/RS. Revista Brasileira de Geografia Física, v.6, n.3, p.500-509, 2013. DOI: https://doi.org/10.26848/rbgf.v6.3.p500-509

NUNES, M. L. A.; GOMES, J. B.; WEBLER, A. D.; ANDRADE, L. R.; MARCHETTO, M.. Comprometimento da qualidade da água subterrânea por nitratos. Revista Nucleus v.9, p.63-72, 2012. DOI: http://dx.doi.org/10.3738/1982.2278.638

OLIVEIRA, G. A.; NASCIMENTO, E. L.; ROSA, A. L. D.; LAUTHARTTE, L. C.; BASTOS, W. R.; BARROS, C. G. D.; CREMONESE, E. R.; BENT, A. Q.; MALM, O.; GEORGIN, J.; CORTI, A. M.. Avaliação da qualidade da água subterrânea: Estudo de caso de Vilhena/RO. Revista Brasileira das Águas Subterrâneas, v.29, n.2, p.213-223, 2015. DOI: http://doi.org/10.14295/ras.v29i2.28399

OLIVEIRA, G. A.; VIEGA, J. F. V.; ROSA, A. L. D.; PESSOA, J. O.; SILVA, J. L. S.. Avaliação da vulnerabilidade intrínseca das águas subterrâneas do município de Porto Velho/RO. Revista de Engenharia e Tecnologia, v.8, p.187-198, 2016.

PEEL, M. C.; FINLAYSON, B. L.; MCMAHON, T. A.. Updated World Map of the Köppen-Geiger Climate Classification. Hydrol. Earth Syst. Sci., v.11, p.1633-1644, 2007. DOI: https://doi.org/10.5194/hess-11-1633-2007

RAVIKUMAR, P.; SOMASHEKAR, R. K.. Principal component analysis and hydrochemical facies characterization to evaluate groundwater quality in Varahi river basin, Karnataka state, India. Applied Water Science, v.7, n.2, p.745-755, 2017. DOI: https://doi.org/10.1007/s13201$\underline{015-0287-x}$

SANTOS, A. S. R. M.; MAURO, T. L.; SOUZA, L. A.; SENIGALIA, R. L. C.; CASTRO, D. A.; SANTOS, E. S.. Métodos de classificação supervisionada aplicados no uso e ocupação do solo no munícipio de Presidente Médice/RO. Biodiversidade, v.18, n.1, 2019.

SILVA, A. C. S.; DOURADO, J. C.; KRUSCHE, A. V.; GOMES, B. M.. Impacto físico-químico da deposição de esgotos em fossas sobre as águas de aquífero freático em Ji-Paraná - RO. Revista de Estudos Ambientais, v.11, n.2, p.101-112, 2009. DOI: http://dx.doi.org/10.7867/1983-1501.2009v11n2p101112.

SILVA, D. D.; MIGLIORINI, R. B.; SILVA, E. C.; LIMA, Z. M.; MOURA, I. B.. Falta de saneamento básico e as águas subterrâneas em aquífero freático: região do Bairro Pedra Noventa, Cuiabá (MT). Revista Engenharia Sanitária e Ambiental, v.19, n.1, p.43-52, 2014. DOI: http://dx.doi.org/10.1590/S1413-41522014000100005

SILVA, L. C. M.; BROTTO, M. E.. Nitrato em água: Ocorrência e consequências. Faculdade Oswaldo Cruz. São Paulo, 2014.

SPERLING, M. V.. Introdução à qualidade das águas e ao tratamento de esgotos. Belo Horizonte: UFMG, 2014.

VARNIER, C.; HIRATA, R.. Contaminação da água subterrânea por nitrato no parque ecológico do Tietê-São Paulo, Brasil. Revista Águas Subterrâneas, v.16, n.1, p.97-104, 2002. DOI: https://doi.org/10.14295/ras.v16i1.1303

VARNIER, C.; IRITANI, M. A.; VIOTTI, M.; ODA, G. H.; FERREIRA, L. M. R.. Nitrato nas águas subterrâneas do sistema aquífero Bauru, área urbana do município de Marília (SP). Revista do Instituto Geológico, São Paulo, v.31, p.1-21, 2010. DOI: http://dx.doi.org/10.5935/0100-929X.20100001

VÖRÖSMARTY, C. J.; GREEN, P.; SALISBURY, J.; LAMMERS, R. B.. Global water resources: vulnerability from climate change and population growth. Science, v.289, n.5477, p.284-288, 2000. DOI: https://doi.org/10.1126/science.289.5477.284

VÖRÖSMARTY, C. J.; MCINTYRE, P. B.; GESSNER, M. O.; DUDGEON, D.; PRUSEVICH, A.; GREEN, P.; GLIDDEN, S.; BUNN, S. E.; SULLIVAN, C. A.; REIDY LIERMANN, C.; DAVIES, P. M.. Global threats to human water security and river biodiversity. Nature, v.467, n.7315, p.555, 2010. DOI: https://doi.org/10.1038/nature09440

WU, J.; LI, P.; QIAN, H.; DUAN, Z.; ZHANG, X.. Using correlation and multivariate statistical analysis to identify hydrogeochemical processes affecting the major ion chemistry of waters: case study in Laoheba phosphorite mine in Sichuan, China. Arab J. Geosci, v.7, n.10, p.39733982, 2014. DOI: https://doi.org/10.1007 / s12517-013$\underline{1057-4}$

A CBPC - Companhia Brasileira de Produção Científica (CNPJ: 11.221.422/0001-03) detém os direitos materiais desta publicação. Os direitos referem-se à publicação do trabalho em qualquer parte do mundo, incluindo os direitos às renovações, expansões e disseminações da contribuição, bem como outros direitos subsidiários. Todos os trabalhos publicados eletronicamente poderão posteriormente ser publicados em coletâneas impressas sob coordenação da Sustenere Publishing, da Companhia Brasileira de Produção Científica e seus parceiros autorizados. Os (as) autores (as) preservam os direitos autorais, mas não têm permissão para a publicação da contribuição em outro meio, impresso ou digital, em português ou em tradução. 